Kálmán, György C. and Zoltán Z. Varga. "Introduction to Comparative Studies in the Central European Context." Hungarian Cultural Studies. e-Journal of the American Hungarian Educators Association, Volume 10 (2017) DOI: 10.5195/ahea.2017.306

\title{
Introduction to Comparative Studies in the Central European Context
}

\author{
György C. Kálmán and Zoltán Z. Varga
}

\begin{abstract}
As an introduction to the four papers published in the 2017 issue of Hungarian Cultural Studies, this paper summarizes the specificities of comparative literary studies in the Central and Eastern European context, as examined by a research group affiliated with the Institute of Literary Studies, the Hungarian Academy of Sciences and various other universities throughout Hungary. The topics and thoughts expressed in these studies were originally explored during a conference session held at the AILC Vienna Congress in 2016. While Central and Eastern Europe's participation in the world of comparative studies has formed a core element for both the research group's interest and the Vienna session, this field has been expanded to discuss Central and Eastern European literatures within the context of international comparative studies as well as the migration (emigration) of these literatures. After presenting the four papers included in the 2017 issue of Hungarian Cultural Studies, the Guest Editors provide a brief preview of the next four papers to be published in the journal's 2018 issue.
\end{abstract}

Keywords: Comparative literature, Hungarian literature, AILC Vienna Congress

Biographies: György C. Kálmán graduated in aesthetics and literature from ELTE, Budapest, in 1977 and has been a researcher at the Institute for Literary Studies of the Hungarian Academy of Sciences since 1984. For over a decade he has taught as a professor of literature at the University of Pécs. He received his CSc in 1990 for his thesis on speech acts and literary theory. Kálmán's main fields are literary theory and twentieth-century and contemporary literature, sociological and linguistic approaches to literature and interpretation. His book, Elharcok és arcélek (2008) ['Vanguards and Profiles'], focuses on the beginnings of the avant-garde movement in Hungary. He is a practicing critic and has published multiple studies and volumes on literary theory and Hungarian literature, and he is also active in journalism. gckalman@gmail.com

Zoltán Z. Varga is Senior Researcher in the Department of Literary Theory at the Institute for Literary Studies, Research Center for the Humanities of the Hungarian Academy of Sciences, Budapest. He is a Lecturer at the Department of Modern Literary History and Theory of Literature at the University of Pécs. His main fields of research are autobiographical genres in modern literature, comparative literature and modern Hungarian literature. His $\mathrm{Ph}$. D. thesis explored issues surrounding autobiographical fragments in modern Hungarian literature. He has published several papers in Hungarian, French and English. He is a member of IABA-Europe (International Auto/Biographic Association) and the International Comparative Literature Association (ICLA). Since 2013, Zoltán Z. Varga has served as Managing Editor of the international comparative literature journal, Neohelicon.

z.varga.zoltan@btk.mta.hu 
Kálmán, György C. and Zoltán Z. Varga. "Introduction to Comparative Studies in the Central European Context." Hungarian Cultural Studies. e-Journal of the American Hungarian Educators Association, Volume 10 (2017) DOI: 10.5195/ahea.2017.306

Examining how the field of comparative literature was influenced by developments in Central Europe particularly highlights how the circumstances leading to the emergence of a new field of study determine its study and evolution. Although the joint term "Central and Eastern European" is used throughout this introduction so as to include the former Eastern Bloc (or "socialist") countries (excluding Austria, for example) together with the former Soviet Union, the focus of this cluster is primarily on Hungary. Even if issues, circumstances and traditions were fairly similar in all of the former Eastern Bloc countries, the situation in Hungary was slightly more favorable, thereby allowing Hungarian researchers to pursue the study of comparative literature with relative freedom. Attempting to define something as apparently simple and obvious as the geopolitical and regional circumstances, which define comparative studies in Hungary has already directed awareness toward the need for scholars to balance the universal while grappling with the local.

If one poses the question of whether the specific characteristics and unique features of contemporary comparative studies in Central Europe warrant increased scholarly attention, the response to this must be a resounding yes followed by an equally emphatic no. The latter, negative reply can be explained by the fact that comparative literature in Central and Eastern Europe today displays the same methodological and theoretical plurality found in comparative studies throughout the rest of the world. In Central Europe today it can be said that the humanities - including comparative literature - have become a part of the globalized theoretical and academic universe. Before World War II, Central and Eastern European theoretical schools were in the vanguard of the discipline of comparative studies and acted as pioneers in founding key aspects of literary theory as well as the institutions upon which this field was established. One must only refer to the Russian formalists, the Czech structuralists and the work of Mikhail Bakhtin to understand the significant role filled by Central and Eastern Europe in comparative studies.

In the aftermath of the Second World War and following the region's take-over by communist dictatorships, the situation changed dramatically as Central Europe's cultural and academic scene fell under state control and remained directed by political and ideological demands throughout the Cold War period. As a result, Central Europe's unique regional identity was forcibly removed from global consciousness: the historical concept of "Mitteleuropa" was dissolved into a gray area existing somewhere beyond the ideological wall dividing the map between the West and the Soviet bloc. Within the global consciousness, Central Europe became designated as Eastern Europe. It can therefore be stated that in Central Europe the field of comparative studies was uniquely affected by a variety of historical and political circumstances that determined scholarly discourse.

Within the Iron Curtain, state bans restricted opportunities for the exchange of any new ideas or theories originating from countries ruled by the "decadent bourgeoisie" determined to cling to a so-called "collapsing" system of capitalism. Interestingly enough, the field of comparative literature was sometimes able to circumvent this situation by engaging in a handful of international collaborations, such as by participating in the International Comparative Literature Association (ICLA). While mostly Hungarian scholars were present at these events, it is worth noting that researchers from Czechoslovakia, Romania, Poland and Eastern Germany were also able to attend ICLA's congresses or even accept positions on the association's board. Once communist rule collapsed Central Europe underwent a whirlwind of privatization that was not just economic in nature: to refer to a process described by Pierre Bourdieu (1979), the 
Kálmán, György C. and Zoltán Z. Varga. "Introduction to Comparative Studies in the Central European Context." Hungarian Cultural Studies. e-Journal of the American Hungarian Educators Association, Volume 10 (2017) DOI: 10.5195/ahea.2017.306

region's intellectual capital was also privatized by current Western theories such as deconstruction and post-structuralism. These schools of thought were later followed by cultural and gender studies as well as post-colonialism. It is due to these briefly outlined chapters in Central Europe's twentieth-century history that a researcher today can travel from any part of the world to attend a conference in Budapest, Prague or Warsaw and still find the same terminology, theories and methods being applied to comparative studies.

To return to the original question of whether Central European comparative studies possesses its own specific nature, the answer to this can also be affirmative given the fact that the recently imported theories mentioned above were in turn re-appropriated by the region's local intellectual and artistic traditions. In the social sciences as well as in literary theory, these textual and especially cultural "turns" were reinterpreted by means of focusing on the historical and cultural peculiarities of the region itself. Via this characteristic process of "cultural transfer" as described by Michel Werner and Michel d'Espagne (cf. Espagne and Werner, 1994), not only have fields of investigation and subjects of research changed, but also (to some extent) methodological assumptions. To give one example, within Central and Eastern Europe, cultural criticism focuses on post-communist social heritage while gender studies pinpoints the politicalideological formations exhibited by gender roles. While the region's the lack of a colonial paststrictly speaking - would seem to disqualify Central Europe from engaging in the theories surrounding colonialism, post-colonialism studies were transformed into analyses examining different minority situations as well as investigations of social exclusion due to ethnic, linguistic, or other reasons. (In spite of this, a journal called Postcolonial Europe contains articles with titles such as, "Postcolonial Studies and Postsocialism in Eastern Europe." The journal, Postcolonial or Postdependancy Studies, sometimes includes discussions on countries like Poland, for example.)

It can therefore be stated that in the Central European context, comparative studies are essentially global in that these fields share the same contextual and interdisciplinary approaches, diversity of themes and theoretical framework as can be found in international comparative literature. Yet comparative studies are also local, for the type of comparative research currently being conducted in Central Europe remains deeply rooted in local intellectual traditions and a given political and historical context. As a result, scholars transform methodological assumptions based on theories originating from Western schools of thought. Comparative research has diffused the relational nature of research in each national literature; given the widespread and universal nature of multi-, inter- and transnational/cultural/linguistic exchanges, comparative analyses have been instrumental in demonstrating how futile it is to view national literatures as closed and therefore completely independent entities.

Without making any claim to providing a comprehensive overview, six points can be given for the purpose of outlined a few features and topics characterizing comparative literature studies in the Central European context.

1. Poetical and textual commitment. Thanks to formalist and structuralist traditions that continue to exert a strong influence on the region, comparative analysis still focuses on the question of how cultural, political and social issues are transformed into a textual reality. Cultural poetics is intrinsically bound to close-reading practices, the theory of genres and narratological analysis. 
Kálmán, György C. and Zoltán Z. Varga. "Introduction to Comparative Studies in the Central European Context." Hungarian Cultural Studies. e-Journal of the American Hungarian Educators Association, Volume 10 (2017) DOI: 10.5195/ahea.2017.306

2. A predominance of historical subjects. Even contemporary cultural and social issues (exile, migration, newborn anti-Semitism, etc.) are often treated as problems originating in the past.

3. Focus on the historical heritage of a multiethnic, multicultural and multilinguistic Mitteleuropa, particularly in reference to the former Austro-Hungarian Empire and regions such as Transylvania, Prague or Vienna.

4. The cultural poetics of modernity (as both an artistic and social movement, i.e., a vehicle of social progress), including the exchange and conflicts between international modernist endeavors versus national traditions.

5. Studies on regional exchanges, brought about by literary, artistic, philosophical contact within Central Europe.

6. The archaeology of literary, artistic and scholarly institutions, investigations surrounding their role in worldwide exchange and the flux of ideas and forms. In short, these concepts provide an abbreviated guide to understanding the main issues underlying the comparative examinations featured in this current issue of Hungarian Cultural Studies.

An ever-widening group of Hungarian literature specialists from various universities and academic institutions throughout Hungary have grown increasingly aware of the fact that the history of comparative literary studies in Hungary and the field's contribution to the worldwide discipline (its history, circumstances, prominent figures, institutional background etc.) are topics worthy of more serious examination and thorough analysis. The members of our research group include Tamás Berkes, György Fogarasi, Sándor Hites, Péter Hajdu, Éva Jeney, György C. Kálmán, János Mekis, Dorottya Szávai and Zoltán Z. Varga, who have been actively cooperating with other members of the Institute for Literary Studies of the Research Center for Humanities and the Hungarian Academy of Sciences, namely Dávid Szolláth and Gábor Bezeczky (Department of Literary Theory) and Zsófia Kalavszky (Department of Eastern European Studies). In 2014, it was with the goal of exploring the topics mentioned above that our research group applied for and received a grant from OTKA (Hungary's National Scholarly Research Fund, OTKA No. K 112415) in order to examine at least certain aspects of comparative literary studies.

In Hungary, the official history of comparative literature studies began in the 1971 when the Hungarian National Committee of the International Comparative Literature Association (ICLA) was established. As we already discussed earlier in our research project's grant materials, the most outstanding achievement of this decade was hosting the ICLA congress in 1976, Hungarian scholars have been very active in the life of this international organization and have filled many important positions, including the presidency of György Mihály Vajda, for instance. As was previously mentioned, during the 1970s and 1980s ICLA presented a tremendous opportunity for Central and Eastern European scholars to be involved in Western academic life while simultaneously broadening their knowledge of theoretical and ideological issues. By underscoring Hungarian literary history's interwoven nature within the context of world literature and the co-dependent nature of local and European traditions, this spirit of cooperation between Hungary and the international community enriched the field of Hungarian literary studies. In the years following the fall of the Iron Curtain in 1989, several conferences were organized to promote local Hungarian comparative studies, an effort usually conducted together with ICLA representatives. Needless to say, Hungarian scholars remain active participants in ICLA's international community. 
Kálmán, György C. and Zoltán Z. Varga. "Introduction to Comparative Studies in the Central European Context." Hungarian Cultural Studies. e-Journal of the American Hungarian Educators Association, Volume 10 (2017) DOI: 10.5195/ahea.2017.306

It must not be forgotten that Hungarian literature does not figure merely in the context of world literature. The common, historical experience brought about by the Habsburg Empire, socialism and post-socialism makes it vitally important to view Hungarian literature through the lens of Central Europe, the region to which it belongs. Our project was preceded - and hence aided and inspired — by the prominent research of Dionýz Durišin (Ďrišin 1997-1998). The cooperation of numerous scholars who contributed to four thick volumes on the comparative literary history of Central and Eastern Europe, edited by John Neubauer and Marcel Cornis-Pope (2004-10), also provided an excellent basis for our own endeavors. Important works such as these paved the way towards a new possible approach to Hungarian literature, too: while this task still awaits completion, the theoretical framework has been established for the Hungarian scholarly community to begin producing their own contribution. Some recent publications suggest that the impact these books possess should be taken seriously (e.g. Sabatos 2013).

As our research expanded, it became increasingly obvious that the project of exploring Central and Eastern Europe's participation in the world of comparative studies was ripe for more public attention; the ICLA Congress held in Vienna in 2016 furnished the perfect opportunity for Central European literature specialists to bring their ideas concerning the regional embeddedness of literary cultures to this most open of international forums. Originally, a workshop was to be held as a part of the congress for the purpose of discussing the issue of literary interrelatedness in Central Europe, with mostly Central European colleagues in attendance. The workshop session at the 2016 Vienna Congress was called "Comparative Studies in Central European Context." The call for papers emphasized a focus on comparative studies' local (Central and Eastern European) contribution to global scholarship from multiples points of view.

First and foremost, the history of literary studies attests to the fact that comparative studies were strongly emphasized — sometimes for political reasons — and formed a means of escape from the narrow constraints created by the totalitarian control of socialism's cultural ideology in Central and Eastern Europe. Some fields (e.g., translation theory) were even internationally acknowledged as having been pioneered by Central European scholars. Second, comparative studies in the region have always possessed a special place straddling the border of literatures and arts from the East as well as from Central Europe itself, resulting in the cultural interface of Eastern/Western influences, similarities, homologies, etc. Third, emigration has played a crucial political and cultural role in the region. In literary and scholarly works by émigrés from Central or Eastern Europe, unique, transnational perspectives of comparison have emerged regarding linguistic and cultural exchanges, formations of memory and identity, assimilation and dissimilation. Not only were papers discussing the special Central and Eastern European history of comparative studies welcome, but examinations addressing regional comparisons and issues surrounding emigration/immigration, language changes, linguistic isolation, etc. were judged as equally important

It could be argued that drawing a distinct line between Hungarian literature and European literature - even for the sake of holding a workshop - echoes thought patterns or habits stemming from the age of nationalism; nowadays this emphasis has been modified, while this separation has itself been fundamentally reinterpreted. There may have been periods when Hungarian literature could be considered conservative and provincial in many respects, leading to the repetition of its own past, that is, its earlier European character. It can also be claimed that Hungarian literature has not taken a leading or definitive role in adding to the process of European literature's constant renewal. While these statements are conceivable, they still do not 
Kálmán, György C. and Zoltán Z. Varga. "Introduction to Comparative Studies in the Central European Context." Hungarian Cultural Studies. e-Journal of the American Hungarian Educators Association, Volume 10 (2017) DOI: 10.5195/ahea.2017.306

mean that Hungarian literature disappeared from its network of relations with other European literatures. Nor did it join another network of relations: whether deemed provincial or conservative, eccentric of isolates, all of the seemingly divergent paths taken by Hungarian literature can be interpreted and comprehended against the backdrop of other European literatures. Studying Hungarian literature as a history of the influence exercised by European literatures will not only eliminate the opposition between national and world literature, but also dissolve their artificial and historical separation. Simultaneously, viewing Hungarian literature through this lens will clearly demonstrate how this relatively small literature has enriched traditions central to the European canon. The question of what ripples of influence a work or author has generated in European literature can be answered via the results and facts found in Hungarian literature, a process, by which interest may also be awakened toward works of Hungarian literature..

The four studies published in this 2017 issue of Hungarian Cultural Studies form the first of a two-part of a cluster entitled "Comparative Studies in Central European Context." Together with the studies to be published in the cluster's continuation in the 2018 issue, these papers provide a representative cross-section of the kind of comparative research being conducted in Central Europe today. While each researcher has focused on topics and works originating from Hungarian literature, each subject is also explored within a comparative context, meaning that great emphasis is placed on the dialogue Hungarian authors, scholars and works carry out with the ideas, forms and genres found in world literature. Similarly, the papers in this cluster discuss how these phenomena change and are ultimately transformed within the national context of Hungary.

The papers by Péter Hajdu and Zsófia Kalavszky serve as compelling examples of how the technique of close reading (based on classical poetical analysis) can be combined with cultural poetics. In her examination of the influence Aleksandr Pushkin had on the Hungarian author, Gyula Krúdy, Kalavszky introduces readers to literary cult research, one of Hungarian literary scholarship's most influential theoretical currents during the past few decades. Literary cult research examines literature as social practice and thereby analyzes phenomena related to the social usage of literature, such as how writers or their fictional creatures embody collective ideals and ideas, how these perceptions come to represent the values of real historical communities and the kinds of social action that allow these ideals to be maintained and propagated. In her analysis, Kalavszky combines literary cult research - a field related to the sociology of literature - with a close reading approach, resulting in a detailed study of how the Pushkin cult and myth were reinterpreted and reappropriated by the modernist Hungarian author, Gyula Krúdy, in his novel, The Crimson Coach. In Krúdy's work the author's unrealistic, fictional world intermingles with the cult of Pushkin and the protagonist of his eponymous work, Onegin, to create a cult of the sensitive and melancholic artist, offering a reflective and slightly ironic representation of the Pushkin cult during this period in Hungary.

In his article, Péter Hajdu turns to a textual tradition in comparative studies by employing careful narrative analysis while simultaneously drawing from an extensive background in generic theory. Hajdu interprets a short story by Mór Jókai, the renowned, nineteenth-century, Hungarian novelist, in an effort to determine if this Central European narrative can be read as a detective story avant la lettre. By comparing the fictional inquiry presented in Jókai's "The Star of the Magi" to the generic models for detective story outlined in twentieth-century poetics, Hajdu concludes that "in Jókai's nineteenth-century, Central European narrative, the detective story is 
Kálmán, György C. and Zoltán Z. Varga. "Introduction to Comparative Studies in the Central European Context." Hungarian Cultural Studies. e-Journal of the American Hungarian Educators Association, Volume 10 (2017) DOI: 10.5195/ahea.2017.306

embedded into a wide context, in which a love story and the national history play essential roles exhibiting a complex relationship to the crime." As a result, Hajdu expands his generic investigations to form a genuine comparative analysis with the purpose of describing how generic patterns in fin-de-siècle Hungarian literature revealed a combination of various narrative and generic patterns (i.e., the love story or anecdotal story-telling) while remaining embedded in the socio-political context of the time, as shown by the national rivalry between Hungarians and the oppressive, German authority depicted in "The Star of the Magi."

Dávid Szolláth's case study examines how anti-Semitism and anti-modernism influenced modernism's reception in Hungary in the decades between 1908 and 1930. After a brief historical and social overview of the period, he analyzes how and why anti-Semitic arguments entered literary debates. Szolláth shows that conservatives regarded the aim of transferring aestheticism, late Symbolism and decadence as an attack against the nation's patriotic traditions. Anxiety surrounding the purported "failed assimilation" of Hungarian Jews/Jewry was further compounded by the fear that a foreign culture would have an undue impact on Hungarian literature. As a part of his discussion concerning identity and assimilation, Szolláth guides readers through the social pathways followed by three Hungarian authors from different familial and ethnic backgrounds as a means of illustrating "how the nationalist discourse on assimilation could be internalized within separate individuals." Szolláth's examination points to how the issue of assimilation manifested itself in literary debates as a question of linguistic competence, leading anti-modernist (and anti-Semitic) discourses to distort modernist attempts in poetical innovation and experimentation as attacks against the "purity" of the Hungarian language.

Annamária Codău's paper returns to the early history of comparative literature in Hungarian via her analysis of the difficulties encountered by the very first international journal of comparative literature, Összehasonlitó Irodalomtörténelmi Lapok/Acta Comparationis Litterarum Universarum (ACLU), a multilingual literary journal published in Kolozsvár/ClujNapoca/Klausenburg from 1877 to 1888. In this highly interesting case study, Codău examines how the initial aim of Hugo Meltzl and Sámuel Brassai, journal's founding editors, was completely misunderstood by the Hungarian scholarly community as well as the nation's official cultural politics. Based on an adaptation of Goethe's Weltliteratur, the journal's goal was to draw numerous peoples of the world closer to one another through mutual translation and thereby align a national culture's interests and values with a world literary perspective. Within the political-historical context possessed by the multi-ethnic and multilingual region of Transylvania at the time of the Austro-Hungarian Empire, the editors' aim also had a political impact. Despite the editors' sincere intentions to reduce nationalist tensions among various ethnic and linguistic communities by sparking a mutual interest in each other's culture and literature, the journal faced a cold reception from Hungarian scholars who had a different vision for representing Hungarian culture and literature on the international literary scene. By following the role filled by one of the journal's British contributors, Codău's paper brings the conflicts surrounding these two different visions concerning the relationship of Hungarian and world literature to life for today's readers.

Our cluster also contains three critical reviews of volumes discussing topics closely related to the comparative research presented in our selection of articles. Peter Sherwood's review on Worlds of Hungarian Writing - National Literature as Intercultural Exchange (eds. by Kiséry, András, Zsolt Komáromy and Zsuzsanna Varga, 2016) enjoys a direct connection to the dialogue between Hungarian and world literature explored in our cluster. To some extent, the four articles in this issue's cluster can be viewed as an extension of the enterprise embarked on 
Kálmán, György C. and Zoltán Z. Varga. "Introduction to Comparative Studies in the Central European Context." Hungarian Cultural Studies. e-Journal of the American Hungarian Educators Association, Volume 10 (2017) DOI: 10.5195/ahea.2017.306

by this volume's three editors. In his insightful evaluation Sherwood outlines the reason why new comparative approaches are needed for presenting Hungarian literature to an international, English-speaking readership. Maya J. Lo Bello's review of Mary Gluck’s The Invisible Jewish Budapest: Metropolitan Culture at the Fin de Siècle acts as the counterpart to Dávid Szolláth's paper on anti-Semitism, insofar as she introduces and contextualizes Mary Gluck's book on flourishing Jewish (popular and urban) culture in fin-de-siècle Budapest. As for András Kiséry's review on Helga Lénárt-Cheng and Zsuzsa Vajdovics's biography of Sándor Lénárt ( Lénárt Sándor: Világok Vándora ['Alexander Lenard: Wanderer of Worlds']), his critical introduction to this volume on the issue of exile and life writing will surely echo throughout the second part of our selection of articles on "Comparative Studies in the Central European Context" to follow in 2018 .

The 2018 issue of Hungarian Cultural Studies will feature a further selection of papers read at ICLA's Vienna Congress session. In his analysis, Comparative Literature in a Totalitarian Age: the Strange Case of East-Central Europe, György C. Kálmán will focus on the personal and institutional connections and mutual influences joining ICLA and Hungarian scholarship. In the 1960s and 1970s, the totalitarian state control of culture in Central and Eastern Europe was very tight: publication as well as the flow of information was kept under strict surveillance, while individuals had few opportunities to travel or access information via libraries, journals, etc.These decades, however, also marked a time when quite a number of researchers were able to participate in the international comparative literary scene, a paradox deserving a measure of reflection. The paper will discuss that during this period, why comparative literary studies were so important for students of literature in this region, how and why those in power (temporarily and selectively) lifted the restrictions imposed upon the entire sphere of culture. What price (if any) did participants have to pay for this liberty? The author will also investigate if this was a personal privilege bestowed upon a few, carefully selected scholars for the purpose of propaganda, or rather an institutional triumph attained by the scholarly community. The question of whether the situation's political impact influenced research done by these comparatists will also be addressed. In his attempt to formulate tentative answers to the issues mentioned above, Kálmán provides readers with examples of how Central and Eastern European scholars participated in international events during the period.

Zoltán Z. Varga's forthcoming paper, Cultural Identities, Historical Traumas and Personal Paths in Eastern European Emigrés' Autobiographies: Susan Suleiman's Budapest Diary and Endre Karátson's Otthonok [Homes], focuses on works of life writings by two intellectuals who also happened to be scholars in comparative literature. Similarly, both authors were born in Hungary before World War II and left the country in their youth. Their autobiographic works depict an image of Eastern Europe within its modern historical context and including the era's intellectual atmosphere. This image of Eastern Europe-or, more precisely, Hungary - during the twentieth century is viewed from the double position of both the native and the stranger. Although these two examples of life writing express this double bind in slightly different ways - one exhibit a greater influence by the adoptive culture, while the native culture dominates in the other one-both authors focus on collective identity patterns. As they reflect on identity-constructions determined by local history and culture, Suleiman and Karátson do so by telling their own personal stories and revealing private and even intimate aspects of their lives. Both autobiographical works seek to render the cultural and historical inheritance manifested in their personal paths in order to imbue their past deeds and opinions with meaning as a form of 
Kálmán, György C. and Zoltán Z. Varga. "Introduction to Comparative Studies in the Central European Context." Hungarian Cultural Studies. e-Journal of the American Hungarian Educators Association, Volume 10 (2017) DOI: 10.5195/ahea.2017.306

East-West exchange. In his paper Zoltán Z. Varga will examine how these authors try to extend the meaning of "home," by making peace with their past both in the collective as well as personal dimension, providing readers with an intimate, yet also transcultural dialogue carried out with an absent other, represented by her mother in the case of Suleiman and his wife in the case of Karátson.

György Fogarasi's article entitled On Idioms and Idiotisms (Theodore Thass-Thienemann: The Interpretation of Language I-II) analyzes a later work by the leading Hungarian linguist and literary historian from the first half of the 20th century, Tivadar Thienemann (born 1890). Also strongly committed to comparative studies, Thienemann left a robust oeuvre (including monographs, dictionaries, academic positions, periodicals and book series) behind when he decided to leave Hungary in 1947. After initially emigrating to Belgium, Thienemann later moved to the United States, where he worked as a psychiatrist and freelance intellectual until his death in 1985. Fogarasi's paper will focus on the final stage of Thienemann's career, via writings Thienemann authored during the 1960s and 1970s as "Theodore Thass-Thienemann." The core of Fogarasi's investigation consists of Thienemann's two-volume book, The Interpretation of Language, a work situated at the intersection of psychoanalysis and language philosophy. While this work seems bluntly metaphysical at times (due to its tiresomely universalistic and humanistic claims), at other times it is boldly provocative thanks to the author's semi-conscious suggestions regarding the etymological entanglements of specific word clusters traversing linguistic, historical and cultural borders. Theinemann's work may therefore serve to link the question of multilinguism to both twentieth-century comparative research in Central and Eastern Europe and the emblematic figure of the emigrated comparatist.

Zsuzsanna Varga's paper entitled Imagining Comparative Literature: Hungarian Women Writers in the Nineteenth Century focuses on works by Emília Kánya and the Wohl sisters, women whose roles as periodical editors and journalists in Pest-Buda during the 1860s and 1870s makes them stand out as important examples today. Their periodicals, Családi Kör (1860) ['Family Circle'] and Magyar Bazár (1872) ['Hungarian Bazaar'] introduced Hungarian readers to European literature in translation while also featuring reviews and critical essays that compared Hungarian and foreign works. In her study Varga will examine their literary careers and editorial activities in tandem before analyzing pieces of literary journalism. As Varga argues, as tempting as it may be to view the emergence of comparative literature as a recent phenomenon, nineteenth-century practical criticism actually worked in close collaboration with this emerging scholarly discipline.

\section{Works Cited}

Bourdieu, Pierre. 1979. "Les trois états du capital culturel” ["The Three Levels of Cultural Capital"]. Actes de la recherche en sciences sociales, 3-6.

Durišin, Dionýz. 1997-98. Medziliterárny centrizmus stredoeurópskych literatúr. ['Interliterary Center of Central European Literatures'] 1-2, České Budějovice : Jihočeská univerzita.

Espagne, Michel and Michael Werner. 1994. Qu'est-ce qu'une littérature nationale? : approches pour une théorie interculturelle du champ littéraire. ['What is a National Literature? Toward an Intercultural Theory of the Literary Field'] Paris: Éd. de la Maison des sciences de l'homme. 
Kálmán, György C. and Zoltán Z. Varga. "Introduction to Comparative Studies in the Central European Context." Hungarian Cultural Studies. e-Journal of the American Hungarian Educators Association, Volume 10 (2017) DOI: 10.5195/ahea.2017.306

Neubauer, John and Cornis-Pope, Marcel, Eds. 2004-10. History of the Literary Cultures of EastCentral Europe: Junctures and Disjunctures in the 19th and 20th Centuries. 1-4. Amsterdam: John Benjamin'.

Sabatos, Charles D. 2013. Toward a Median Context: Comparative Approaches to Central European Literature. World Literature Studies 5.2: 29-38. 